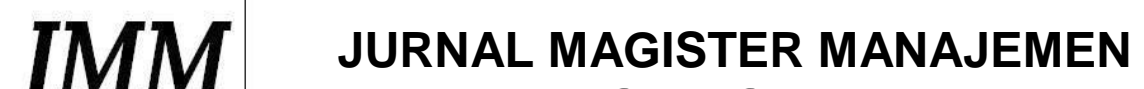 UNIVERSITAS MATARAM

\section{PENERAPAN BALANCED SCORECARD SEBAGAI INDIKATOR DALAM PENGUKURAN KINERJA KOPERASI (STUDI PADA KPRI KARYA DHARMA SELONG)}

\author{
Abdul Haris' \\ Lilik Handayani2 \\ Endar Paturingsih ${ }^{2}$
}

\begin{abstract}
This study aims to determine the performance of KPRI "Karya Dharma" Selong from a financial perspective, customer perspective, internal business processes, learning and growth perspective through the Balanced Scorecard analysis. The method used is descriptive method. A study on the phenomenon or population obtained by researchers of the subject in the form of individual, organizational, industry or any other perspective. The data used in this study comes from the Annual Member Meeting Report of KPRI "Dharma Karya" Selong fiscal year 2011 to fiscal year 2015. These results indicate that the performance measurement results KPRI "Dharma Karya" Selong seen from the perspective of financial and customer perspective is generally considered "fair". Meanwhile, if viewed from the perspective of internal business processes and learning and growth perspective is generally rated "Good". The implication of this finding is that KPRI "Dharma Karya" Selong can apply the method Balanced Scorecard as a performance measurement system that can measure the performance of the cooperative of cooperatives in a comprehensive or exhaustive.

Keywords: Performance Measurement, Financial Perspective, Customer Perspective, internal business processes, learning and growth perspective, Balanced Scorecard
\end{abstract}

\section{PENDAHULUAN}

\section{1 . Latar Belakang Penelitian}

Koperasi sebagai salah satu organisasi yang tidak hanya mementingkan perolehan laba semata, memiliki karakteristik penting yang terlihat dari fungsi dan peran yang diamanatkan oleh Undang Undang No. 25 Tahun 1992 yang diantaranya adalah membangun dan mengembangkan potensi dan kemampuan ekonomi anggota pada khususnya dan masyarakat pada umumnya untuk meningkatkan kesejahteraan ekonomi dan sosialnya. Akan tetapi pada kenyataannya koperasi belum bisa melakukan penilaian kinerja secara baik (Ikhsan, 2009).

Penilaian kinerja KPRI "Karya Dharma" belum dilakukan dengan metode Balanced Scorecard, tetapi hanya mengacu pada penelitian kinerja secara tradisional, yaitu menggunakan analisis laporan keuangan (rasio keuangan). Selama ini, KPRI "Karya Dharma" hanya menggunakan indikator rasio keuangan seperti rasio likuiditas, rasio solvabilitas, rasio ROE dan ROI untuk menilai kinerjanya. Namun, berdasarkan tujuan dan strategi yang dimiliki oleh KPRI "Karya Dharma", indikator pengukuran kinerja keuangan yang telah yang digunakan

\footnotetext{
${ }^{1}$ Mahasiswa Program Magister Akuntansi UNRAM

${ }^{2}$ Dosen Program Magister Akuntansi UNRAM
} 


\section{JMM JUNALL MACSTRE MANAEEEN UNIVERSITAS MATARAM

perlu ditambahkan penilaian kinerja dari ketiga perspektif Balanced Scorecard lainnya. Keunggulan penerapan Balanced Scorecard adalah dapat memberikan ukuran yang dapat dijadikan sebagai dasar dalam perbaikan strategis perusahaan.

Balanced Scorecard adalah alat yang cocok untuk mengevaluasi serta merancang strategi operasional (Dodangh, 2010). Andrew Pateman (2008), Balanced Scorecard adalah sebuah alat bisnis yang menghubungkan strategy dan tindakan perusahaan. Jovanovic (2009), Balanced Scorecard merupakan arah strategi untuk sistem pengukuran dan peningkatan kinerja organisasi yang mengusulkan empat perspektif strategi. Pembagian strategi, tujuan serta ukuran kinerja ke dalam empat perspektif kinerja bisnis sekaligus menegaskan bahwa kinerja keuangan tidak dapat berdiri sendiri dalam mengukur keberhasilan suatu perusahaan (Gunawan, 2009).

Beberapa penelitian terkait Balanced Scorecard telah banyak dilakukan khususnya pada perusahaan-perusahaan manufaktur yang berorientasi pada laba. Sementara untuk perusahaan-perusahaan nirlaba khususnya yang bergerak pada Usaha Koperasi masih jarang dilakukan. Penelitian yang dilakukan oleh Puspita (2003), terkait penerapan model ukuran Balanced Scorecard pada PT Semen Gresik (Persero) Tbk. menunjukkan bahwa penerapan ukuran balanced scorecard terhadap perusahaan agar kinerja perusahaan menjadi lebih baik. Yunan (2008) melakukan penelitian dengan judul: Penerapan Balanced Scorecard Sebagai Tolok Ukur Kinerja Manajemen pada PT. Bank Tabungan Negara (Persero) Cabang Malang. Hasil penelitian menjelaskan bahwa pengukuran kinerja menggunakan Balanced Scorecard dapat diterapkan pada PT. Bank Tabungan Negara (Persero) Cabang Malang, karena telah memenuhi data-data yang telah dibutuhkan untuk analisis kinerja berdasarkan empat perspektif dalam Balanced Scorecard.

Perbedaan penelitian ini dengan beberapa penelitian terdahulu terletak pada obyek penelitian dimana, penelitian-penelitian sebelumnya dilakukan di perusahaan - perusahaan yang berorientasi laba, sementara dalam penelitian ini menggunakan analisis balanced score card untuk menilai kinerja usaha non-profit oriented khususnya pada unit usaha Koperasi. Disamping itu, Koperasi KPRI “Karya Dharma “ Selong sampai dengan tahun 2015 melakukan penilaian kinerja usahanya dengan melihat hanya dari perspektif keuangannya saja.

Berdasarkan uraian diatas, maka dilakukan penerapan Balanced Scorecard agar tolok ukur pengukuran kinerja Koperasi KPRI "Karya Dharma" Selong dapat berjalan secara baik. Mengingat pentingnya Balanced Scorcard dalam pengukuran kinerja perusahaan. Maka peneliti mengambil judul "Penerapan Balanced Scorecard sebagai Indikator dalam Pengukuran Kinerja Koperasi (Studi pada KPRI Karya Dharma Selong).

\subsection{Landasan Teori}

\section{TINJAUAN PUSTAKA}

\subsubsection{Konsep Balanced Scorecard}

Konsep Balanced Scorecard berkembang sejalan dengan perkembangan implementasi konsep tersebut. Kaplan dan Norton menyatakan bahwa Balanced Scorecard terdiri dari kartu skor (scorecard) dan berimbang (balanced). Kartu skor adalah kartu yang digunakan untuk mencatat skor hasil kinerja seseorang. Kartu skor juga dapat digunakan untuk merencanakan skor yang hendak diwujudkan oleh personel di masa depan. Melalui kartu skor, skor yang akan diwujudkan personel di masa depan dibandingkan dengan hasil kinerja sesungguhnya. Hasil perbandingan ini digunakan untuk melakukan evaluasi atas kinerja personel yang 


\section{JMM JUNALL MACSTRE MANAEEEN UNIVERSITAS MATARAM

bersangkutan. Kata berimbang dimaksudkan untuk menunjukkan bahwa kinerja personel diukur secara berimbang dari dua aspek: keuangan dan nonkeuangan, jangka pendek dan jangka panjang, intern dan ekstern. Oleh sebab itu, personel harus mempertimbangkan keseimbangan antara pencapaian kinerja keuangan dan non-keuangan, antara kinerja jangka pendek dan jangka panjang, serta antara kinerja yang bersifat intern dan yang bersifat ekstern jika kartu skor personel digunakan untuk merencanakan skor yang hendak diwujudkan di masa depan.

Balanced scorecard mengembangkan seperangkat tujuan unit bisnis melampaui rangkuman unit finansial. Para eksekutif perusahaan sekarang dapat mengukur berbagai unit bisnis mereka dengan menciptakan nilai bagi para pelanggan perusahaan saat ini dan yang akan datang dan seberapa banyak perusahaan harus meningkatkan kemampuan internal dan investasi di dalam sumber daya manusia, sistem dan prosedur yang dibutuhkan untuk meningkatkan kinerja yang akan datang. Balanced Scorecard mencakup berbagai aktivitas penciptaan nilai yang dihasilkan dan para partisipan perusahaan yang memiliki kemampuan dan motivasi yang tinggi. (Kaplan dan Norton, 1996: 7).

\subsubsection{Perspektif Balanced Scorecard}

Menurut Keplan dan Norton (2000), empat perspektif balanced scorecard mencakup perspektif keuangan, perspektif pelanggan, perspektif proses bisnis internal, dan perspektif pembelajaran dan pertumbuhan. Untuk lebih detailnya, keempat perspektif tersebut dapat dijelaskan sebagai berikut:

1) Perspektif Keuangan

Balanced scorecard mempertahankan sudut pandang finansial karena ukuran finansial sangat bernilai dalam merangkum semua konsekuensi ekonomi yang terukur dari semua tindakan yang dilakukan. Contoh, dengan menggunakan operating income, return on capital employed, economic value added, return on investment, return on equity (Keplan dan Norton (2000)).

2) Perspektif Pelanggan

Pada sudut pandang customers dari balanced scorecard, manajer mengenal segmen dari market dan customer yang mana unit bisnis akan bersaing dan ukuran dari kinerja unit bisnis pada segmen yang ditargetkan. Contoh: kepuasan pelanggan, customer retention, customer profitability, dan market share (Keplan dan Norton (2000)).

3) Perspektif Proses Bisnis Internal

Ukuran dari internal business process fokus pada proses internal yang memiliki dampak yang sangat besar bagi kepuasan pelanggan dan mencapai tujuan finansial dari perusahaan (Keplan dan Norton (2000)). Perbedaan dari internal business process yang tradisional dengan internal business process dengan pendekatan balanced scorecard, yaitu konsep tradisional hanya fokus dalam memonitor dan mengembangkan proses yang telah ada.

4) Perspektif Pembelajaran dan Pertumbuhan

Pada sudut pandang ini, menurut Keplan dan Norton (2000), perusahaan harus secara terus menerus mengembangkan kemampuan untuk mengirimkan value, dengan kata lain introspeksi, perbaikan, dan pembelajaran agar perusahaan dapat terus bersaing pada persaingan global. Learning and growth organisasi/perusahaan berasal dari 3 sumber: sumber daya manusia, sumber daya informasi, dan budaya organisasi.

\subsubsection{Adaptasi Balanced Scorecard pada Nirlaba}




\section{JMM JUGNAL M MGSTERE MANAEEEN UNIVERSITAS MATARAM

Konsep balanced scorecard yang pada awalnya digunakan untuk mengukur kinerja sektor bisnis, namun dalam perkembangannya ternyata mampu mengembangkan ide dan konsepnya menjadi alat ukur organisasi sektor publik dan nirlaba. Gambar di bawah ini menunjukkan bagaimana kinerja sektor publik dipandang dari konsep balanced scorecard yang telah dimodifikasi instrumen pendukungnya sesuai dengan karakteristik sektor publik

Dalam mengaplikasikan konsep balanced scorecard ke dalam sektor publik, ada beberapa adaptasi dalam instrumen yang perlu dipahami antara lain:

1. Misi menjadi tujuan utama balanced scorecard.

2. Strategi tetap menjadi inti balanced scorecard.

3. Naiknya perspektif kepuasan pelanggan

4. Tidak ada balanced scorecard yang lengkap tanpa perspektif keuangan

5. Identifikasi proses bisnis internal yang akan memberikan nilai pada pelanggan.

6. Pertumbuhan dan pembelajaran menjadi pondasi dalam membangun balanced scorecard yang kuat

\subsection{Penelitian Terdahulu}

Penelitian terdahulu yang relevan dengan penelitian ini, sebagai berikut:

1. Krisbudiman (2015) melakukan penelitian terkait penilaian kinerja kualitas perusahaan manufaktur PT. Yuasa Battery Indonesia dengan metode Balanced Scorecard. Hasil penelitian Krisbudiman (2015) menyimpulkan bahwa dengan menggunakan Balance Scorecard dapat memberikan penilian kinerja yang lebih terstruktur dan komprehensif.

2. Widodo (2010) melakukan penelitian dengan mengambil judul analisis kinerja perusahaan dengan menggunakan pendekatan balanced scorecard (Studi kasus pada perusahaan mebel PT. Jensen Indonesia). Hasil penelitian Widodo (2010) menemukan bahwa kinerja PT Jensen Indonesia dari perspektif keuangan dan perspektif proses bisnis intern berada pada kategori sedang, sementara dari perspektif pembelajaran dan pertumbuhan tergolong baik. Namun jika dilihat dari perspektif pelanggan kinerja PT Jensen Indonesia tergolong kurang baik.

3. Hasil penelitian Monica (2012) menyimpulkan bahwa yang harus dilakkukan oleh perusahaan untuk meningkatkan kinerja keuangan adalah dengan mengelola dan meningkatkan kekuatan (Strength) yang dimiliki, meminimalisir kelemahan yang ada, memperluas kesempatan dan menghindari ancaman- ancaman yang akan timbul.

\subsection{Rerangka Konseptual}

Berdasarkan uraian uraian latar belakang, tinjauan pustaka dan penelitian terdahulu, penelitian ini bertujuan untuk mengetahui kinerja Koperasi KPRI “Karya Dharma” Selong dari perspektif keuangan, perspektif pelanggan, perspektif proses bisnis internal, perspektif pembelajaran dan pertumbuhan melalui analisis Balanced Scorecard. Sehingga rerangka konseptual yang dibangun sebagai berikut: 


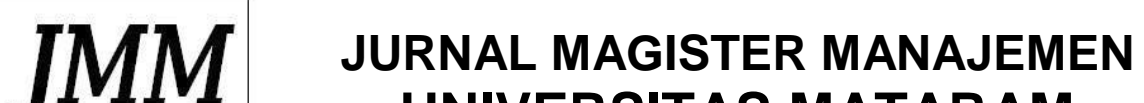 UNIVERSITAS MATARAM

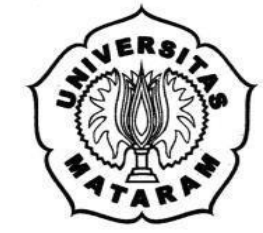

ALUR PIKIR PENELITIAN

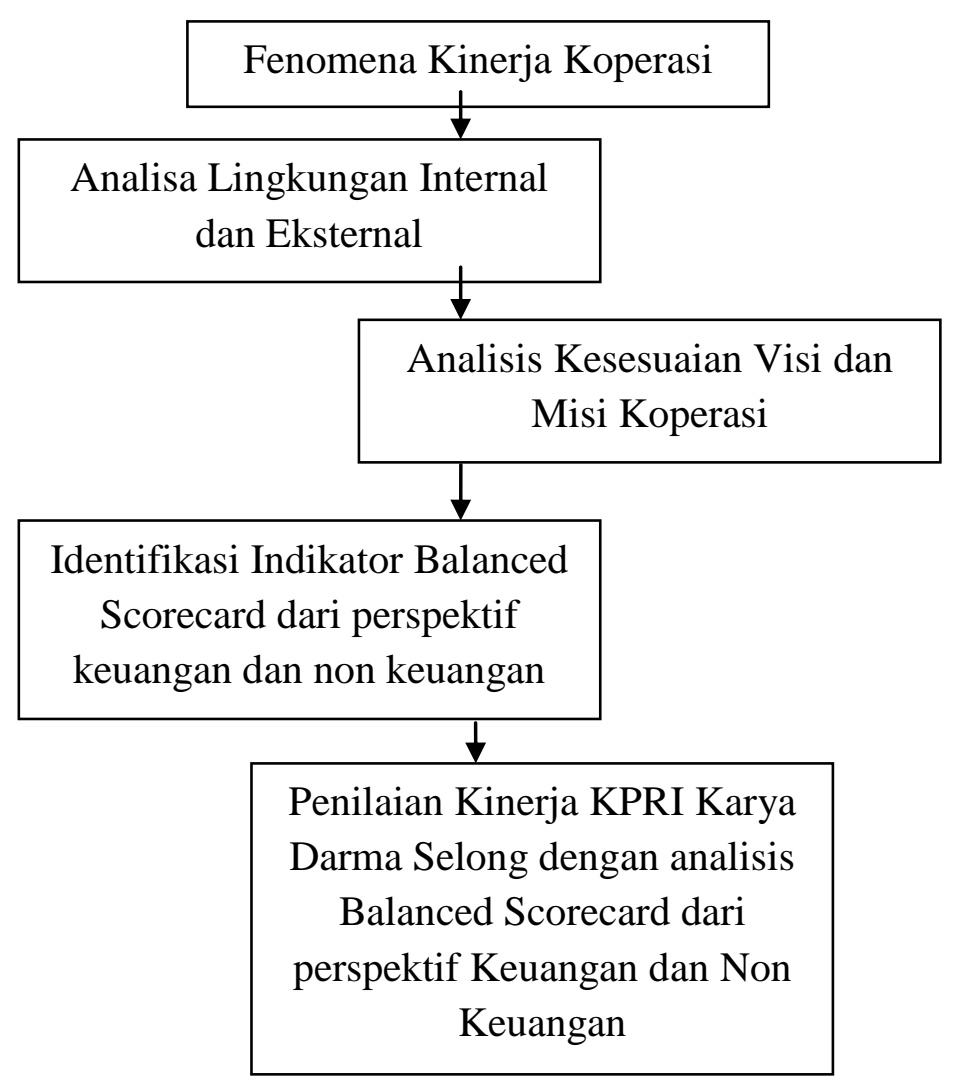

Gambar. 2.3.1 Alur Pikir Penelitian

\section{METODE PENELITIAN}

\subsection{Jenis Penelitian}

Metode penelitian yang akan dipakai adalah metode deskriptif. Yaitu penelitian terhadap fenomena atau populasi tertentu yang diperoleh peneliti dari subyek berupa individu, organisasional, industri atau perspektif lain. Serta menjelaskan karakteristik subyek yang diteliti dan mengkaji berbagai aspek dalam fenomena tertentu kemudian menawarkan ide masalah untuk pengujian atau penelitian selanjutnya (Indriantoro dan Supomo, 1999:88).

\subsection{Data dan Sumber Data}

Data yang digunakan pada penelitian ini bersumber dari Laporan Rapat Anggota Tahunan KPRI “Karya Dharma” Selong tahun buku 2011 sampai dengan tahun buku 2015.

\subsection{Definisi Operasional Variabel}




\section{JMM JUGNAL M MGSTERE MANAEEEN UNIVERSITAS MATARAM

Variabel adalah suatu simbol yang berisi suatu nilai (Neny, 2008). Penelitian ini menggunakan definisi variabel naratif, yaitu definisi dalam bentuk kalimat untuk, menjelaskan makna dan artinya (Jogiyanto, 2007:159). Variabel-variabel dalam penelitian ini adalah sebagai berikut:

1) Kinerja perspektif keuangan dalam penelitian ini diukur menggunakan:

a. Peningkatan Pendapatan

Rasio ini digunakan untuk mengukur seberapa besar kemampuan Unit Simpan Pinjam KPRI "Karya Dharma" Selong dalam mempertahankan dan meningkatkan pendapatannya yang telah dicapai dari satu period eke periode berikutnya. Rasio peningkatan pendapatan Unis Simpan Pinjam KPRI “Karya Dharma" Selong dapat dikatakan baik jika dari periode ke periode berikutnya mengalami trend yang meningkat.

b. Peningkatan SHU

Sisa Hasil Usaha (SHU) sebuah koperasi merupakan salah satu aspek pendapatan bagi anggota. Peningkatan SHU mengindikasikan meningkatnya pendapatan anggota koperasi.

c. Perubahan Biaya

Rasio ini digunakan untuk mengetahui efisiensi biaya yang telah dilakukan KPRI "Karya Dharma" Selong. Rasio perubahan biaya dapat dikatakan baik jika dari periode ke periode berikutnya mengalami trend yang menurun.

d. Rasio Likuiditas (Current ratio)

Rasio likuiditas adalah rasio yang menggambarkan kemampuan suatu perusahaan untuk melunasi semua kewajiban yang harus segera dipenuhi (hutang jangka pendeknya). Perusahaan yang mempunyai cukup kemampuan untuk membayar hutang jangka pendek disebut perusahaan yang likuid sedang bila tidak disebut ilikuid.

Rasio likuiditas yang digunakan dalam peelitian ini adalah current ratio dimana rasio ini membandingkan aktiva lancar dengan hutang lancar. Current Ratio memberikan informasi tentang kemampuan aktiva lancar untuk menutup hutang lancar. Aktiva lancar meliputi kas, piutang dagang, efek, persediaan, dan aktiva lainnya. Sedangkan hutang lancar meliputi hutang dagang, hutang wesel, hutang bank, hutang gaji, dan hutang lainnya yang segera harus dibayar (Sutrisno, 2001:247).

e. Rasio Modal Sendiri dengan Total Aktiva (Solvabilitas)

Rasio solvabilitas adalah kemampuan perusahaan untuk membayar hutang-hutangnya pada saat dilikuidasi. Perusahaan yang mempunyai aktiva/kekayaan yang cukup untuk membayar semua hutang-hutangnya disebut perusahaan yang solvable, sedang yang tidak disebut insolvable. Perusahaan yang solvabel belum tentu ilikuid, demikian juga sebaliknya yang insolvable belum tentu ilikuid.

f. Rasio Rentabilitas Modal (Rentabilitas)

Rasio rentabilitas atau profitabilitas adalah rasio yang digunakan untuk mengukur kemampuan suatu perusahaan dalam mendapatkan laba. Perhatian ditekankan pada rasio ini karena hal ini berkaitan erat dengan kelangsungan hidup perusahaan. 


\section{JMM JUNNAL MACASTER MANASEEEN UNIVERSITAS MATARAM

2) Kinerja perspektif pelanggan dalam penelitian ini diukur menggunakan:

a. Akuisisi Pelanggan

Akuisisi pelanggan adalah kemampuan perusahaan dalam memperoleh pelanggan baru. Akuisisi ini diukur dengan membandingkan jumlah anggota tahun berjalan dengan tahun sebelumnya. Apabila mengalami peningkatan jumlah anggota berarti KPRI “Karya Dharma” Selong dinilai lebih mampu memperoleh anggota baru.

b. Retensi Pelanggan

Retensi pelanggan dilakukan untuk mengukur tingkat kemampuan koperasi dalam mempertahankan hubungannya dengan anggotanya.

c. Rata-rata Laba Per Pelanggan

Kesejateraan anggota merupakan visi dari terbentuknya KPRI "Karya Dharma" Selong. Untuk melihat peningkatan ekonomi anggota KPRI "Karya Dharma" Selong, dengan mengukur rata-rata SHU yang diperoleh masing-masing anggota setiap tahunnya.

3) Pengukuran Kinerja pada Perspektif Proses Bisnis Internal.

a. Proses inovasi

Dalam proses penciptaan nilai tambah bagi pelanggan, proses inovasi merupakan salah satu kritikal proses, dimana efisiensi dan efektifitas serta ketepatan waktu dari proses inovasi ini akan mendorong terjadinya efisiensi biaya pada proses penciptaan nilat tambah bagi pelanggan

b. Proses Operasi

Proses operasi adalah proses untuk membuat dan menyampaikan produk atau jasa. Aktivitas di dalam proses operasi terbagi ke dalam dua bagian: 1) proses pembuatan produk, dan 2) proses penyampaian produk kepada pelanggan.

c. Proses Pelayanan Purna Jual

Proses ini merupakan jasa pelayanan pada pelanggan setelah penjualan produk/jasa tersebut dilakukan. Perusahaan dapat mengukur apakah upayanya dalam pelayanan purna jual ini telah memenuhi harapan pelanggan, dengan menggunakan tolak ukur yang bersifat kualitas, biaya, dan waktu seperti yang dilakukan dalam proses operasi.

4) Pengukuran Kinerja pada Perspektif Pembelajaran dan Pertumbuhan

a. Retensi Karyawan

Retensi karyawan dihitung dengan membandingkan antara jumlah karyawan yang keluar dengan jumlah karyawan tahun berjalan.

b. Produktivitas Karyawan

Produktivitaskaryawan adalah suatu ukuran hasil, dampak keseluruhan usaha peningkatan moral dan keahlian pekerja, inovasi, proses internal, dan kepuasan pelanggan.

c. Kapabilitas Karyawan

Untuk meningkatkan kapabilitas karyawan maka pihak perusahaan mengikutsertakan karyawan yang bersangkutan pada seminar-seminar atau pelatihan-pelatihan baik yang diadakan oleh pihak yang berhubungan dengan KPRI "Karya Dharma" Selong maupun pihak independen.

\subsection{Prosedur Pengambilan dan Pengumpulan Data}




\section{JMM JUGNAL M MGSTERE MANAEEEN UNIVERSITAS MATARAM

Penelitian ini akan dilakukan mulai dari mengunjungi langsung ke lokasi objek penelitian yaitu KPRI “Karya Dharma” Selong dengan tujuan untuk wawancara dengan karyawan yang bekerja pada perusahaan tersebut yang tujuannya untuk mengumpulkan data primer, dan data sekunder dari perusahaan objek penelitian. Langkah selanjutnya mempelajari informasi yang disediakan oleh literatur-literatur baik yang tersedia dalam bentuk buku, karya ilmiah, maupun jurnal yang dapat membantu dalam merancang dan menerapkan balanced scorecard. Data yang berupa data primer hasil dari wawancara, data sekunder dan informasi dari literatur yang digunakan dalam menganalisis pada penelitian ini.

Analisis penelitian akan dimulai dengan memahami apakah KPRI "Karya Dharma" Selong memiliki sistem manajemen, dan sistem pengukuran, yang didapatkan baik dari hasil wawancara maupun informasi yang berasal dari data sekunder. Setelah mengetahui tentang manajemen KPRI "Karya Dharma" Selong, selanjutnya merancang balanced scorecard dengan menggunakan dasar dan informasi yang tersedia dari literatur-literatur yang sesuai, berfungsi sebagai sistem manajemen dan sistem pengukuran kinerja pada KPRI “Karya Dharma” Selong.

Sebelum melakukan analisis balanced scorecard untuk KPRI "Karya Dharma" Selong, ada tiga tahap yang harus dilakukan terlebih dahulu, pertama analisis terhadap lingkungan eksternal dan lingkungan internal koperasi sebagai pedoman dalam perancangan balanced scorecard. Kedua, setelah analisis lingkungan internal dan ligkungan eksternal dari KPRI “Karya Dharma" Selong, menganalisis visi dan misi koperasi. Dan yang ketiga adalah membuat strategy maps dan balanced scorecard KPRI "Karya Dharma" Selong. Langkah terakhir penelitian ini adalah penyerahan usulan balanced scorecard yang telah dirancang termasuk kesimpulan dan saran penelitian yang telah dilakukan, agar bisa menjadi bahan pertimbangan dalam membantu kegiatan bisnis sehari-hari yang dilakukan oleh KPRI “Karya Dharma” Selong.

\subsection{Metode Analisis Data}

Analisis data yang digunakan dalam penelitian ini menggunakan pendekatan empat prespektif Balanced Scorecard dengan mengembangkan pengukuran yang relevan. Adapun keempat perspektif Balanced Scorecard sebagai berikut:

1) Kinerja perspektif keuangan dalam penelitian ini diukur menggunakan:

a. Peningkatan Pendapatan

Rasio ini dirumuskan sebagai berikut:

Peningkatan Pendapatan $=\underline{\text { Pend }}$. Tahun Berjalan - Pend. Tahun lalu $\quad \times 100 \%$

$$
\text { Pendapatan Tahun lalu }
$$

b. Peningkatan SHU

Rasio ini dirumuskan sebagai berikut:

Peningkatan SHU $=\underline{\text { SHU Tahun Berjalan }- \text { SHU Tahun lalu }} \times 100 \%$

SHU Tahun lalu

c. Perubahan Biaya

Rasio ini dirumuskan sebagai berikut:

Perubahan Biaya $=\underline{\text { Biaya Tahun Berjalan }- \text { Biaya Tahun lalu }} \times 100 \%$

\section{Biaya Tahun lalu}

d. Rasio Likuiditas (Current ratio) 


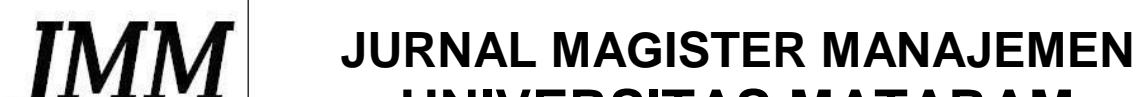 UNIVERSITAS MATARAM

Rasio likuiditas yang digunakan dalam peelitian ini adalah current ratio Rumus Current ratio adalah:

Current Ratio $=$

Aset Lancar $\times 100 \%$

Kewajiban Lancar

e. Rasio Modal Sendiri dengan Total Aktiva (Solvabilitas)

Rasio Modal Sendiri dengan Total Aktiva dirumuskan sebagai berikut:

Equity to Total Assets Ratio $=\quad$ Modal Sendiri $\quad x 100 \%$

Total Aktiva

Sumber : Munawir (Analisis rasio keuangan)

f. Rasio Rentabilitas Modal (Rentabilitas)

Ukuran rasio rentabilitas yang dipakai adalah rasio rentabilitas modal dengan rumusan sebagai berikut:

Rasio Rentabilitas Modal $=\quad \underline{\text { SHU }} \times 100 \%$

Modal

Sumber : Munawir (Analisis rasio laporan keuangan)

2) Kinerja perspektif pelanggan dalam penelitian ini diukur menggunakan:

d. Akuisisi Pelanggan

Akuisisi pelanggan dapat dirumuskan sebagai berikut:

Persentase Akuisisi Pelanggan =

Jumlah Pelangggan Tahun Berjalan - Jumlah Pelanggan Tahun Lalu $x 100 \%$

Jumlah Pelanggan Tahun Lalu

e. Retensi Pelanggan

Retensi pelanggan dilakukan untuk mengukur tingkat kemampuan koperasi dalam mempertahankan hubungannya dengan anggotanya.

f. Rata-rata Laba Per Pelanggan

Rata-rata SHU yang diperoleh pelanggan dapat dirumuskan sebagai berikut:

Rata-Rata SHU Pelanggan =

Total Pelanggan

3) Pengukuran Kinerja pada Perspektif Proses Bisnis Internal.

d. Proses inovasi

Dalam proses penciptaan nilai tambah bagi pelanggan, proses inovasi merupakan salah satu kritikal proses, dimana efisiensi dan efektifitas serta ketepatan waktu dari proses inovasi ini akan mendorong terjadinya efisiensi biaya pada proses penciptaan nilat tambah bagi pelanggan

e. Proses Operasi

Proses operasi adalah proses untuk membuat dan menyampaikan produk atau jasa. Aktivitas di dalam proses operasi terbagi ke dalam dua bagian: 1) proses pembuatan produk, dan 2) proses penyampaian produk kepada pelanggan.

f. Proses Pelayanan Purna Jual 


\section{JMM JUGNAL M MGCSTER MANAEEEN UNIVERSITAS MATARAM

Perusahaan dapat mengukur apakah upayanya dalam pelayanan purna jual ini telah memenuhi harapan pelanggan, dengan menggunakan tolak ukur yang bersifat kualitas, biaya, dan waktu seperti yang dilakukan dalam proses operasi.

4) Pengukuran Kinerja pada Perspektif Pembelajaran dan Pertumbuhan

d. Retensi Karyawan

Retensi karyawan dihitung dengan membandingkan antara jumlah karyawan yang keluar dengan jumlah karyawan tahun berjalan.

e. Produktivitas Karyawan

Produktivitas karyawan merupakan rasio pendapatan perusahaan per karyawan. Dapat dirumuskan sebagai berikut:

Rasio Produktivitas $=\underline{\text { Produktivitas tahun berjalan }- \text { Produktifitas tahun lalu }} \times 100 \%$

Produktivitas Tahun Lalu

f. Kapabilitas Karyawan

Kapabilitas karyawan dapat dirumuskan sebagai berikut:

Rasio Karyawan yang ikut pelatihan = jumlah karyawan yang dilatih $\times 100 \%$

Jumlah Karyawan

\section{HASIL PENELITIAN DAN PEMBAHASAN}

\subsection{HASIL PENELITIAN}

\subsubsection{Gambaran Umum Koperasi}

KPRI “Karya Dharma” Selong berkedudukan di Jln. TGKH. Zainuddin Abdul Majid No. 176 Kelurahan Sandubaya Kecamatan Selong Kabupaten Lombok Timur Provinsi Nusa Tenggara Barat. KPRI "Karya Dharma" Selong didaftarkan pada Dinas Koperasi dan UKM Kabupaten Lombok Timur dengan Badan Hukum No. : 586/BH/XXII tanggal 5 Oktober 1982 dan mengalami Perubahan Badan Hukum No.: 276/BH/PAD/KWK.23/X/1996 tanggal1 Oktober 1996.Anggota KPRI "Karya Dharma" Selong adalah PNS yang mencakup seluruh SKPD se-Kabupaten Lombok Timur.

Latar belakang didirikannya KPRI "Karya Dharma" Selong yaitu dalam rangka ikut berpartisipasi memajukan dan meningkatkan kesejahteraan pegawai negeri khususnya yang ada di lingkungan pemerintah daerah kabupaten Lombok Timur. KPRI "Karya Dharma" Selong dengan kepercayaan dasar yang dimiliki berupaya agar dapat bekerja secara maksimal sehingga dapat berperan dalam meningkatkan kesejahteraan para anggota Koperasi dan keluarganya, membantu anggota dalam menyimpan dananya agar aman serta mendapat tambahan penghasilan dari jasa yang diberikan, membantu tambahan modal bagi anggota yang membutuhkan sehingga usahanya dapat berkembang dan terbebas dari rentenir, membantu anggota yang membutuhkan dana untuk biaya sekolah, berobat dan sebagainya serta berperan dalam mendukung kegiatan sosial di masyarakat.

\subsubsection{Deskripsi Hasil Penelitian}

4.1.2.1 Visi, Misi, dan Budaya KPRI “Karya Dharma” Selong

a. Visi

Visi KPRI “Karya Dharma” Selong adalah "Menjadikan koperasi sebagai harapan utama dalam meningkatkan ekonomi anggota". 


\section{JMM JUGNAL M MACSTER MANASEENEN UNIVERSITAS MATARAM

b. Misi

Sedangkan Misi KPRI “Karya Dharma” Selong yaitu :

1. Meningkatkan kinerja pengelola koperasi (Pengurus, Pengawas dan Karyawan).

2. Meningkatkan partisipasi aktif bagi anggota untuk memanfaatkan jasa pelayanan koperasi.

3. Meningkatkan permodalan dan Sisa Hasil Usaha.

4. Meningkatkan manajemen secara terbuka dan akuntabilitas.

5. Meningkatkan kerjasama dengan pihak lain dengan azas saling menguntungkan.

6. Mengoptimalkan dan mengutamakan pelayanan terhadap anggota.

c. Budaya KPRI “Karya Dharma” Selong

Budaya organisasi adalah suatu sistem nilai dan kepercayaan yang membentuk karyawan, struktur organisasi dan system pengendalian perusahaan untuk memproduksi normanorma keyakinan. Setiap organisasi mempunyai budaya masing-masing, demikian halnya KPRI “Karya Dharma" Selong memiliki budaya yang terus dikembangkan dan dilanjutkan kepada setiap individu dalam organisasi. Adapun budaya KPRI "Karya Dharma" Selong antara lain :

1. Shiddiq (benar dan jujur)

Pengelola memiliki moralitas yang menjunjung tinggi kebenaran dan kejujuran.

2. Tabligh (mengembangkan lingkungan menuju kebaikan)

Pengelola dalam mensosialisasikan peran KPRI "Karya Dharma" Selong harus mengedepankan manfaat bagi anggota dan masyarakat.

3. Amanah (dapat dipercaya)

Pengelola melaksanakan prinsip kehati-hatian dan kejujuran dalam mengelola dana, sehingga timbul rasa saling percaya antara pengelola dengan pihak-pihak terkait.

4. Fathonah (Kompeten dan professional)

Pengelola harus kompeten dan profesional serta memberikan pelayanan dengan cermat, santun, dan penuh tanggung jawab

5. Istiqomah (konsisten)

Pengelola harus selalu konsisten dalam usahanya serta menjunjung tinggi semangat kekeluargaan, kerja sama dan kepedulian sosial.

6. Menjungjung tinggi semangat kekeluargaan, kerja sama dan kepedulian sosial.

\subsubsection{Temuan Hasil Penelitian}

Berdasarkan uraian di atas, terdapat kondisi yang mendukung dilakukannnya penerapan balanced scorecard sebagai system pengukuran kinerja pada KPRI "Karya Dharma" Selong. Kondisi tersebut adalah Karena KPRI "Karya Dharma" Selong telah memiliki visi dan misi yang jelas dan mudah dipahami untuk dituangkan ke dalam konsep-konsep strategi yang jelas. Sehingga dapat mempermudah penyusunan system pengukuran kinerja dengan balanced scorecard.

Analisis data yang dilakukan berdasarkan data yang telah terkumpul adalah sebagai berikut:

4.1.3.1 Menterjemahkan Visi, Misi, dan Strategi ke Dalam Balanced Scorecard

Dalam balanced scorecard, diperlukan adanya kesesuaian antara visi, misi dan rencana strategis pada setiap perspektif. Berdasarkan pada teori balanced scorecard dengan hasil 


\section{JMM JUUNAL M MACSTER MANAEEEN UNIVERSITAS MATARAM

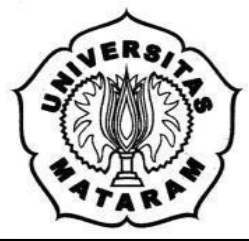

wawancara, dokumen koperasi, dan pengamatan, maka hubungan antara visi, misi dan rencana strategis KPRI “Karya Dharma" Selong dapat digambarkan pada bagan 4.2 berikut :

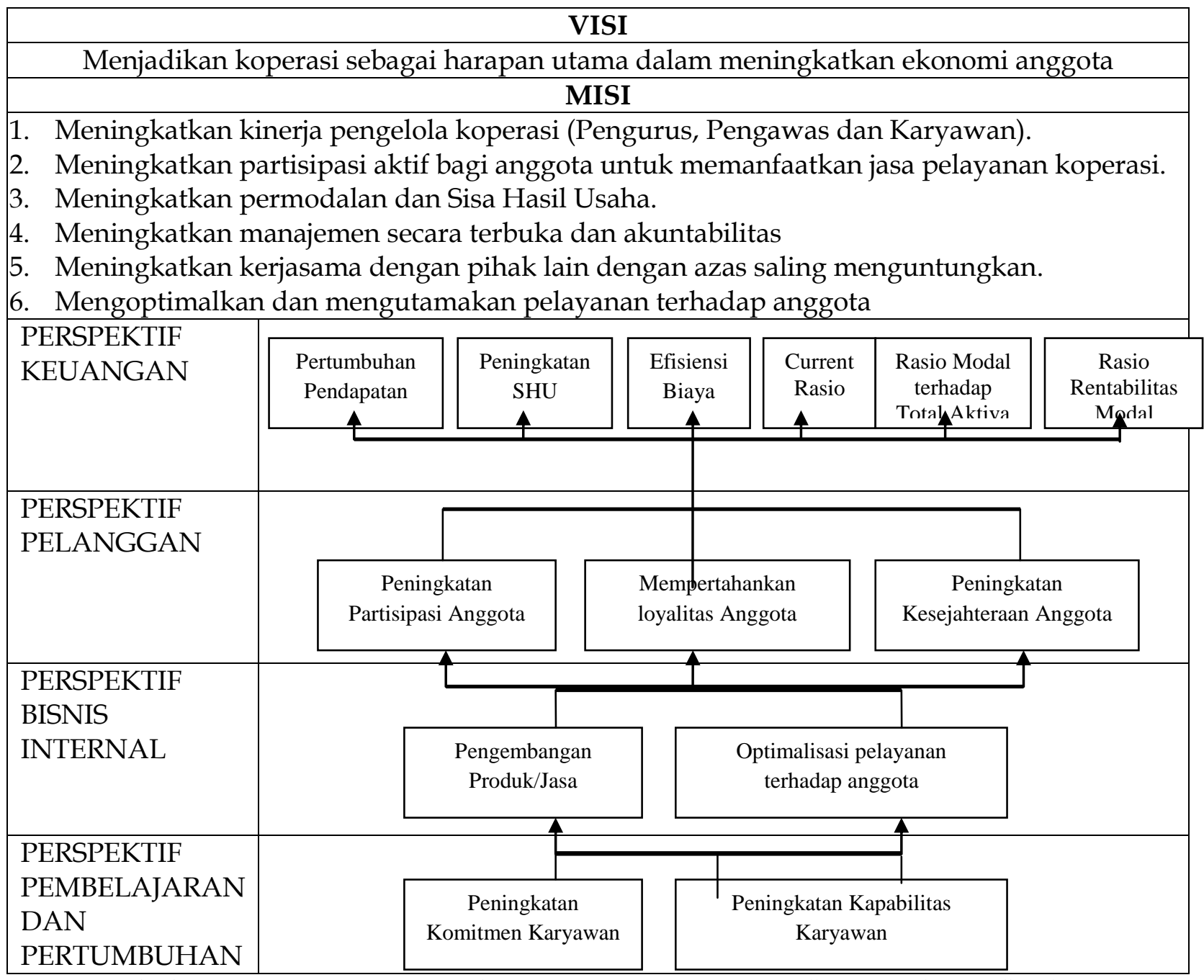

Bagan 4.2 hubungan antara visi, misi dan rencana strategis KPRI “Karya Dharma” Selong

\subsubsection{Pengukuran Kinerja Unit Simpan Pinjam KPRI “Karya Dharma” Selong}

Analisa terhadap pengukuran kinerja pada KPRI "Karya Dharma" Selong dilakukan dengan pendekatan 4 perspektif konsep Balanced Scorecard yaitu : kinerja keuangan, kinerja pelanggan, kinerja proses bisnis internal dan kinerja pembelajaran dan pertumbuhan.

\section{Perspektif Keuangan}

Sasaran dari perspektif keuangan ini adalah untuk memenuhi harapan dari shareholder. Salah satunya adalah dengan cara memperbaiki kinerja operasi perusahaan tersebut. Sehingga profit yang dihasilkan dapat meningkat. Ukuran finansial sangat berguna daalam memberikan gambaran mengenai hasil pengukuran sisi ekonomis atas aktifitas-aktifitas yang diambil perusahaan. Ukuran keuangan sangat penting dalam memberikan ringkasan konsekuensi 


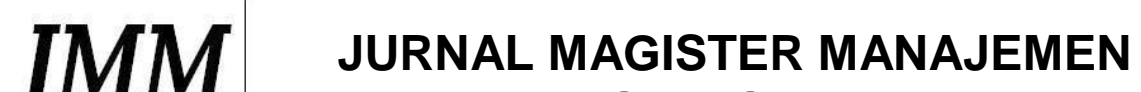 UNIVERSITAS MATARAM

tindakan ekonomi yang telah diambil oleh manajemen. Untuk mengukur perspektif keuangan KPRI “Karya Dharma” Selong, tolak ukur yang digunakan sebagai berikut:

a. Peningkatan Pendapatan

Hasil analisis data menunjukkan bahwa dari tahun ke tahun KPRI "Karya Dharma" Selong mengalami peningkatan pendapatan. Namun, jika dilihat dari rasio pertumbuhan pendapatan, KPRI "Karya Dharma" Selong mengalami trend pertumbuhan yang fluktuatif. Dimana pada tahun 2012 dan 2013 terjadi peningkatan pendapatan sebesar 46,45\% dan 30\% dibanding tahun 2011. Namun di tahun 2014 dan 2015 terjadi penurunan tingkat pendapatan. Kemudian untuk tahun 2016 KPRI “Karya Dharma" Selong kembali mengalami peningkatan pendapatan. Sehingga dapat dikatakan bahwa rasio peningkatan pendapatan KPRI “Karya Dharma” Selong kurang baik.

b. Peningkatan SHU

Hasil analisis data menunjukkan bahwa pada tahun 2013 KPRI "Karya Dharma" Selong mengalami penurunan rasio SHU sebesar 52,74\% dibandingkan tahun 2012. Namun sejak tahun 2014 hingga tahun 2016 KPRI "Karya Dharma" Selong terus mengalami trend peningkatan nilai SHU meskipun kecil. Secara umum, dapat dikatakan bahwa rasio peningkatan pendapatan KPRI “Karya Dharma” Selong cukup baik.

c. Perubahan Biaya

Hasil analisis data menunjukkan bahwa KPRI "Karya Dharma" Selong mengalami penurunan rasio perubahan biaya dari tahun 2013 sampai dengan tahun 2015. Meskipun nilai rasio perubahan biaya menurun pada tahun 2014 dan 2015 tidak signifikan namun secara umum, dapat dikatakan bahwa rasio perubahan biaya KPRI "Karya Dharma" Selong berada pada kategori baik.

d. Rasio Likuiditas (Current ratio)

Hasil analisis data menunjukkan bahwa KPRI "Karya Dharma" Selong memiliki rasio likuiditas yang sehat. Semakin besar perbandingan aktiva lancar dengan hutang lancar, semakin tinggi kemampuan perusahaan menutupi kewajiban jangka pendeknya. Apabila rasio lancar 1:1 atau 100\% berarti bahwa aktiva lancar dapat menutupi semua hutang lancar. Jadi dikatakan sehat jika rasionya berada di atas 1 atau diatas 100\%. Artinya aktiva lancar harus jauh di atas jumlah hutang lancar (Harahap, 2002:301)

e. Rasio Modal Sendiri dengan Total Aktiva (Solvabilitas)

Hasil analisis data menunjukkan bahwa rasio modal sendiri terhadap todal aktiva yang dimiliki KPRI "Karya Dharma" Selong rata-rata di atas 20 persen. Hal ini menunjukkan bahwa KPRI "Karya Dharma" Selong mempunyai aktiva/kekayaan yang cukup untuk membayar semua hutang-hutangnya (Solvabilitas baik). Secara keseluruhan rasio modal sendiri terhadap total aktiva yang dimiliki KPRI "Karya Dharma" Selong dapat dikategorikan "baik".

f. Rasio Rentabilitas Modal (Rentabilitas)

Hasil analisis data menunjukkan bahwa rasio rentabilitas modal KPRI "Karya Dharma" Selong setiap tahun mengalami trend penurunan. Hal ini berarti KPRI "Karya Dharma" Selong tidak mampu memaksimalkan peningkatan jumlah modal yang dimiliki untuk meningkatkan laba dalam bentuk SHU. Sehingga secara keseluruhan, rasio rentabilitas KPRI "Karya Dharma" Selong dinilai "Kurang Baik". 


\section{$J M M$ UNRAM \\ JURNAL MAGISTER MANAJEMEN UNIVERSITAS MATARAM VOL. 6 No. 1 MARET 2017}

2. Perspektif Pelangggan

Fokus perhatian dalam perspektif pelanggan ini adalah untuk melihat bagaimana perusahaan mampu mempertahankan pelanggan yang telah dimiliki dan dapat meningkatkan jumlah pelanggan baru. Tolok ukur yang digunakan untuk mengukur perspektif pelanggaan pada KPRI “Karya Dharma” Selong adalah sebagai berikut :

a. Akuisisi Pelanggan

Hasil analisis data menunjukkan bahwa persentase akuisisi pelanggan KPRI "Karya Dharma" Selong mengalami perubahan fluktiatif. Namun cenderung mengalami penurunan persentasi akuisisi meskipun tidak signifikan. Secara keseluruhan dapat disimpulkan bahwa tingkat akuisisi pelanggan pada KPRI "Karya Dharma" Selong dinilai "Cukup".

b. Retensi Pelanggan

Hasil analisis data menunjukkan bahwa jumlah anggota yang keluar cenderung meningkat setiap tahunnya namun tidak signifikan. Hal ini mengindikasikan bahwa secara keseluruhan nilai retensi pelanggan KPRI “Karya Dharma” Selong tergolong cukup baik.

c. Rata-rata Laba Per Pelanggan

Hasil analisis data menunjukkan bahwa rata-rata laba (SHU) yang diperoleh anggota berfluktuatif setiap tahunnya namun tidak signifikan. Hal ini menunjukkan bahwa KPRI "Karya Dharma" Selong belum dapat meningkatkan kesejahteraan anggotanya secara optimal. Sehingga secara keseluruhan rata-rata laba per pelanggan dianggap cukup.

3. Perspektif Proses Bisnis Internal

Untuk mengukur perspektif ini, KPRI "Karya Dharma" Selong dapat menggunakan tolok ukur sebagai berikut:

a. Proses inovasi

KPRI "Karya Dharma" Selong telah melakukan beberapa inovasi baik melalui produk maupun jasa yang ditawarkan. Sehingga dapat disimpulkan bahwa KPRI "Karya Dharma" Selong telah melakukan inovasi baik produk maupun jasa. Secara keseluruhan proses inovasi yang dilakukan dapat dinilai "baik".

b. Proses Operasi

KPRI "Karya Dharma" Selong dapat dikatakan telah mampu meningkatkan keunggulan koperasi dengan memberikan pelayanan secara cepat dan efisien di tengah persaingan usaha yang kompetitif. Secara keseluruhan proses operasi yang dillakukan dapat dinilai “ baik".

c. Proses Pelayanan Purna Jual

Layanan purna jual yang dilakukan KPRI "Karya Dharma" Selong berupa servis yang responsif, ramah dan terpercaya. Secara keseluruhan proses layanan purna jual yang dilakukan KPRI “Karya Dharma” Selong dapat dinilai baik.

4. Perspektif Pembelajaran dan Pertumbuhan

Proses pembelajaran dan pertumbuhan ini bersumber dari Sumber Daya Manusia, Sistem dan Prosedur Organisasi. Sasaran dari perspektif pembelajaran dan pertumbuhan ini adalah meningkatkan kapabilitas karyawan dan komitmen karyawan. Adapun tolak ukur yang digunakan adalah:

a. Retensi Karyawan 


\section{$J M M$

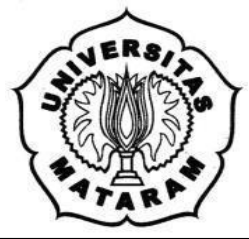

Hasil analisis data menunjukkan bahwa dari tahun 2011 sampai dengan tahun 2015 tidak terdapat pegawai/karyawan di KPRI "Karya Dharma" Selong yang keluar dari kepengurusan. Sehingga bisa disimpulkan bahwa tingkat retensi pegawai di KPRI "Karya Dharma" Selong dinilai " baik".

b. Produktivitas Karyawan

Hasil analisis data menunjukkan bahwa terdapat peningkatan yang cukup signifikan pada tahun 2012 dan 2013. Namun meskipun terjadi peningkatan pada tahun 2014 dan 2015, namun rasio produktivitasnya tidak sesignifikan tahun 2012 dan 2013. Hal ini menunjukkan penurunan tingkat produktivitas karyawan. Sehingga untuk saat ini rasio produktivitas di KPRI “Karya Dharma” Selong dinilai “ cukup”.

c. Kapabilitas Karyawan

Hasil analisis data menunjukkan bahwa setiap tahunnya KPRI “Karya Dharma” Selong selalu mengirimkan karyawannya untuk mengikuti pelatihan-pelatihan maupun seminar yang berkaitan dengan koperasi. Keikut sertaan karyawan dalam pelatihan maupun seminar merupakan proses pembelajaran yang diharapkan mampu meningkatkan kualitas SDM yang selanjutnya dapat memberikan kontribusi bagi kemajuan KPRI "Karya Dharma" Selong. Sehingga secara keseluruhan kapabilitas karyawan pada KPRI “Karya Dharma” Selong dianggap "baik”.

\subsubsection{Penilaian Hasil Pengukuran Kinerja KPRI “Karya Dharma” Selong dengan Balanced} Scorecard

Skala yang digunakan untuk penilaian balanced scorecard dalam penelitian ini adalah stape scale, yaitu skala yang menilai objek yang diteliti diantara angka-angka yang ditentukan (Sekaran dalam Asmoro, 2008).

Tabel 4.12

Rating Scale

\begin{tabular}{|c|c|}
\hline SKOR & Nilai \\
\hline-1 & Kurang \\
\hline 0 & Cukup \\
\hline 1 & Baik \\
\hline
\end{tabular}

Berdasarkan hasil pengukuran terhadap masing-masing perspektif dengan membandingkan data dari tahun ke tahun maka nilai kinerja KPRI "Karya Dharma" Selong dengan menggunakan analisis Balanced Scorecard adalah sebagai berikut: 


\section{JMM UNRAM \\ JURNAL MAGISTER MANAJEMEN UNIVERSITAS MATARAM VOL. 6 No. 1 MARET 2017}

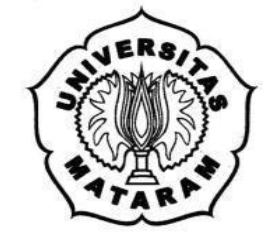

Tabel 4.13

Ikhtisar Hasil Penilaian Kinerja KPRI “Karya Dharma” Selong

\begin{tabular}{|c|c|c|c|c|c|c|c|c|}
\hline \multirow{2}{*}{ No } & \multirow{2}{*}{ Perspektif } & \multicolumn{5}{|c|}{ Tahun } & \multirow{2}{*}{ Kriteria } & \multirow{2}{*}{ Bobot } \\
\hline & & 2011 & 2012 & 2013 & 2014 & 2015 & & \\
\hline & Pers pektif Keuangan & & & & & & & \\
\hline 1 & Rasio peningkatan pendapatan & & $46.45 \%$ & $30.14 \%$ & $9.02 \%$ & 8.79 & Kurang & -1 \\
\hline 2 & rasio peningkatan SHU & - & $-53.21 \%$ & $-52.72 \%$ & $5.83 \%$ & $6.35 \%$ & Cukup & o \\
\hline 3 & Rasio perubahan biaya & - & $69.71 \%$ & $30.05 \%$ & $9.28 \%$ & $8.99 \%$ & Baik & 1 \\
\hline 4 & Ras io Likuiditas & $1734.93 \%$ & $1069 \%$ & $1292 \%$ & $754 \%$ & $690 \%$ & Baik & 1 \\
\hline 5 & Rasio Modal terhadap Aktiva & $24.06 \%$ & $23.06 \%$ & $23.45 \%$ & $38.86 \%$ & $46.30 \%$ & Baik & 1 \\
\hline \multirow[t]{2}{*}{6} & Rasio Rentabilitas Modal & $10.73 \%$ & $13.15 \%$ & $8.71 \%$ & $3.32 \%$ & $2.78 \%$ & Kurang & -1 \\
\hline & Perspektif Pelanggan & & & & & & & \\
\hline 7 & Akuis is i Pelanggan & - & $27.51 \%$ & $7.23 \%$ & $7.91 \%$ & $-2.99 \%$ & Cukup & o \\
\hline 8 & Retensi Pelanggan & $0.29 \%$ & $2.36 \%$ & $3.54 \%$ & $5.50 \%$ & $7.26 \%$ & Cukup & o \\
\hline \multirow[t]{2}{*}{9} & Rata-Rata Laba per Pelanggan & 250,570 & 301,076 & 211,381 & 129,293 & 140,622 & Cukup & o \\
\hline & Pers pektif Proses Bisnis Internal & & & & & & & \\
\hline 10 & Proses Inovasi & & & & & & Baik & 1 \\
\hline 11 & Proses Operasi & & & & & & Baik & 1 \\
\hline \multirow[t]{2}{*}{12} & Proses Pelayanan Purna Jual & & & & & & Baik & 1 \\
\hline & Pers pektif Pembelajaran dan Pert & ahan & & & & & & \\
\hline 13 & Retensi Karyawan & & & & & & Baik & 1 \\
\hline 14 & Produktivitas Karyawan & & $32 \%$ & $30 \%$ & $9 \%$ & $9 \%$ & Cukup & o \\
\hline \multirow[t]{2}{*}{15} & Kapabilitas Karyawan & $22 \%$ & $20 \%$ & $20 \%$ & $30 \%$ & $40 \%$ & Baik & 1 \\
\hline & Total & & & & & & & 6 \\
\hline
\end{tabular}

Sumber: KPRI “Karya Dharma” Selong (Data Diolah)

Hasil penilaian kinerja pada tabel 4.13 di atas merupakan hasil Analisa dari data-data yang tersaji. Tabel 4.13 menunjukkan hasil penilaian kinerja, yang dilakukan dengan konsep balanced scorecard yang didasarkan pada penilaian skor. Pengukurann kinerja dengan balanced scorecard memiliki total bobot skor 6 dari total bobot standar 15. Sehingga rata-rata skor adalah $6 / 15=0,40$.

Selanjutnya, menentukan skala untuk menilai total skor. Menurut Pramono (Dalam Riah, 2009) skala kinerja untuk perusahaan dapat ditentukan sebagai berikut:

a. Kinerja tertinggi, yaitu kinerja diatas $80 \%$ = rata-rata skor 0,60 - 1,00 yang menunjukkan . Kinerja Perusahaan Baik".

b. Kinerja Rata- Rata, yaitu kinerja antara 50\% - 80\% = Skor 0 - 0,60 yang menunjukkan “ Kinerja Perusahaan Cukup Baik"

c. Kinerja terendah, yaitu kinerja yang kurang dari $50 \%=$ skor $-1-0$ yang menunjukkan "Kinerja Perusahaan Buruk".

Dengan demikian, dapat diartikan bahwa kinerja KPRI "Karya Dharma" Selong apabila diukur dengan metode Balanced Scorecard terletak di daerah "Kinerja Perusahaan Cukup Baik" Karena nilainya 0,4 yang terletak diantara $0-0,60$ atau diantara $50 \%-80 \%$. 


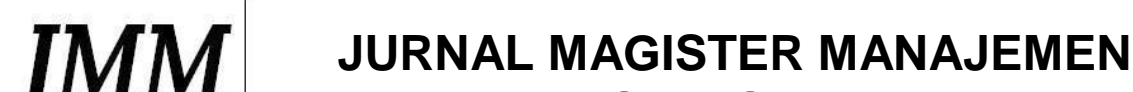 UNIVERSITAS MATARAM

\section{PENUTUP}

\subsection{Simpulan}

Berdasarkan pembahasan hasil penelitian, maka dapat ditarik kesimpulan sebagai berikut :

a. Hasil pengukuran kinerja KPRI "Karya Dharma" Selong dilihat dari perspektif keuangan secara umum dinilai "cukup". Hal ini dapat dilihat dari peningkatan pendapatan yang mengalami penurunan, rasio peningkatan SHU meningkat namun tidak signifikan, rasio perubahan biaya berada dalam kategori baik, Rasio Likuiditas yang sehat. Rasio Modal Sendiri terhadap Aktiva dikategorikan "baik". Namun, KPRI "Karya Dharma” Selong tidak mampu memaksimalkan peningkatan jumlah modal yang dimiliki untuk meningkatkan laba dalam bentuk SHU.

b. Hasil pengukuran kinerja KPRI “Karya Dharma” Selong dilihat dari perspektif pelanggan secara umum dinilai "Cukup". Hal ini dapat dilihat dari persentase akuisisi pelanggan KPRI "Karya Dharma" Selong mengalami perubahan fluktiatif. Sehingga dinilai "Cukup". Nilai retensi pelanggan KPRI "Karya Dharma" Selong tergolong cukup baik. Rata-rata laba (SHU) yang diperoleh anggota berfluktuatif setiap tahunnya namun tidak signifikan. Hal ini menunjukkan bahwa KPRI "Karya Dharma" Selong belum dapat meningkatkan kesejahteraan anggotanya secara optimal.

c. Hasil pengukuran kinerja KPRI "Karya Dharma" Selong dilihat dari perspektif proses bisnis internal secara umum dinilai "Baik". KPRI "Karya Dharma" Selong telah melakukan inovasi baik produk maupun jasa. Selain itu, KPRI “Karya Dharma" Selong dapat dikatakan telah mampu meningkatkan keunggulan koperasi dengan memberikan pelayanan secara cepat dan efisien di tengah persaingan usaha yang kompetitif. Proses Pelayanan Purna Jual yang dilakukan KPRI "Karya Dharma" Selong berupa servis yang responsif, ramah dan terpercaya. Pihak KPRI "Karya Dharma" Selong mengatasi keluhan-keluhan pelanggan dengan azas kekeluargaan. Sehingga, secara keseluruhan proses layanan purna jual yang dilakukan KPRI "Karya Dharma” Selong dapat dinilai baik.

d. Hasil pengukuran kinerja KPRI "Karya Dharma" Selong dilihat dari perspektif pembelajaran dan pertumbuhan secara umum dinilai "Baik". Hal ini dapat dilihat bahwa dari tahun 2011 sampai dengan tahun 2015 tidak terdapat pegawai/karyawan di KPRI "Karya Dharma" Selong yang keluar dari kepengurusan. Sehingga bisa disimpulkan bahwa tingkat retensi pegawai di KPRI "Karya Dharma" Selong dinilai " baik. rasio produktifitas menunjukkan penurunan tingkat produktivitas karyawan namun tidak signifikan sehingga dinilai " cukup". Untuk meningkatkan kapabilitas karyawan, KPRI "Karya Dharma" Selong selalu mengirimkan karyawannya untuk mengikuti pelatihan-pelatihan maupun seminar yang berkaitan dengan koperasi. Sehingga secara keseluruhan kapabilitas karyawan pada KPRI "Karya Dharma" Selong dianggap "baik".

\subsection{Implikasi Penelitian}

Berdasarkan kesimpulan di atas, maka dapat dilihat implikasi dari hasil penelitian tersebut. Implikasi hasil penelitian dapat berupa dampak teoritis terhadap usaha pengembangan ilmu pengetahuan atau penelitian, penerapannya secara praktis dan implikasi terkait kebijakan yang dapat diambil. 


\section{JMM JUNALL MACSTRE MANAEEEN UNIVERSITAS MATARAM

Secara teoritis, hasil penelitian ini memperkuat teori di bidang Akuntansi Manajemen, bahwa metode Balanced Scorecard dapat diterapkan sebagai sistem pengukuran kinerja perusahaan secara komprehensif atau menyeluruh melalui empat perspektif yaitu perspektif keuangan, perspektif pelanggan, perspektif proses bisnis internal, dan perspektif pembelajaran dan pertumbuhan pada badan usaha berbentuk koperasi.

Secara praktis, berdasarkan analisis data dan pembahasan maka KPRI "Karya Dharma" Selong dapat menerapkan metode Balanced Scorecard sebagai system pengukuran kinerja koperasi yang dapat mengukur kinerja koperasi secara komprehensif atau menyeluruh.

Secara kebijakan, hasil analisis pada penelitian ini dapat dijadikan sebagai bahan masukan untuk peningkatan perkembangan KPRI "Karya Dharma" Selong sebagai upaya untuk melakukan perbaikan manajemen. Hasil penelitian ini diharapkan mampu meningkatkan kinerja koperasi KPRI "Karya Dharma" Selong dan perlu disesuaikan dengan kondisi KPRI "Karya Dharma" Selong saat ini.

\subsection{Keterbatasan dan Saran}

\subsubsection{Keterbatasan Penelitian}

Penelitian ini memiliki keterbatasan yang dapat diperbaiki pada penelitian selanjutnya. Keterbatasan yang harus dicermati dan saran terhadap keterbatasan yang ditemui oleh peneliti dalam penelitian, antara lain adalah :

1. Kemungkinan kurang tepatnya ukuran yang digunakan dalam menentukan tolak ukur dari masing-masing perspektif. Scorecard disusun berdasarkan konsep balanced scorecard yang dipandang paling mungkin dan mudah untuk diterapkan di Koperasi, Karena itu scorecard bukanlah hasil mutlak dari konsep Balanced Scorecard.

2. Ruang lingkup penelitian yang masih terbatas pada KPRI "Karya Dharma" Selong sehingga generalisasi hasil temuan dan rekomendasi penelitian ini kurang dapat diberlakukan bagi koperasi lainnya. Oleh karena itu untuk mendapatkan kesimpulan yang bersifat umum perlu dilakukan penelitian yang lebih luas.

\subsubsection{Saran}

1. Bagi Penelitian Selanjutnya

a. Untuk penelitian selanjutnya agar dapat melakukan pengukuran lebih menyeluruh terhadap berbagai aspek. Diantaranya ukuran pengsa pasar, kapabilitas system informasi, dan tingkat kepuasan karyawan.

b. Penelitian selanjutnya diharapkan dapat melakukan pengukuran kinerja pada Koperasi dengan lingkup yang lebih luas sehingga diharapkan dapat menjadi bahan informasi bagi pengelola Koperasi maupun lembaga keuangan lainnya.

2. Bagi Manajemen KPRI "Karya Dharma" Selong

a. Dalam iklim persaingan usaha yang semakin kompetitif, KPRI "Karya Dharma" Selong sebaiknya mulai mencoba menerapkan metode balanced scorecard.

b. Dalam penyususnan rencana strategis, KPRI "Karya Dharma" Selong perlu melakukan perencanaan jangka panjang secara tertulis dan lebih mendetail sesuai dengan visi dan misi yang diinginkan.

c. Dari keempat perspektif, hasil yyang masih kurang baik adalah pada perspektif keuangan dan perspektif pelanggan. Sehingga KPRI "Karya Dharma" Selong diharapkan melakukan perbaikan untuk meningkatkan hasil kedua perspektif tersebut. 


\section{JMM JUGNAL M MGSTER M MANAEENEN UNIVERSITAS MATARAM

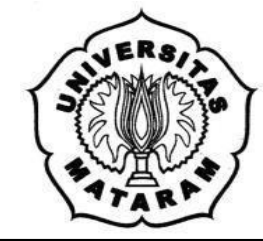

\section{DAFTAR PUSTAKA}

Anand, Manonj. 2005. Balanced Scorecard in Indian Companies. Executive Summary volume 30.

Andrew Pateman, 2008. Lingking Strategy to Operation: Six Stage to Execution. Business Performance Management Magazine.

Anthony, Atkinson,el al. 1995. Managemen Accounting (International Edition) New Jersey. England Cliffs: Prantice- Hall International Inc.

Dodangh, Javad, Majid Mojehed and Vahid Nasehifar. 2010. Ranking of Strategic Plans in Balanced Scorecard by Using Electric Method. International Journal of Innovation, Management and Technology, Vol. 1, No. 3, h: 269-274.

Groene Oliver, Elimer B, dan Johannes M. 2009. "The Balanced Scorecard of Acute Settings: Development Process, Definition of 20 Strategi Objectives And Implementation". International Journal For Quality In Health Care.

Gunawan, Ketut. 2009. Analisis Faktor Kinerja Organisasi Lembaga Perkreditan Desa di Bali (Suatu Pendekatan Perspektif Balanced Scorecard). http://puslit.petra.ac.id/files/published/journals.

Ikhsan, Sukardi. 2009. Penerapan Balanced Scorecard Sebagai Tolak Ukur Kinerja Pada KPRI di Jawa Tengah. Dalam Jurnal Dinamika Akuntansi, Vol. 1, No. 2: h:117-124.

Jogiyanto HM., Akt., MBA,Ph.D. 2007. Metodologi Penelitian Sistem Informasi.Yogyakarta: C.V Andi Offset.

Jovanovic, Jelena. 2009. Balanced Scorecard Model Evaluation : The Case of AD Barska Plovidba. Montenegero: Faculty of Mechanical Engineering. http//: www.mitpress_mit.edu/ije.

Karra, Eleni D. 2005. The Evaluation of an Academic Institution using the Balanced Scorecard (Academic Scorecard): The Case of University of Macedonia, Thessaloniki, Greece. http//:www.ssrn.com.

Kaplan, Robert S., Norton, David P. (Peter S. Yosi Pasla, Penerjemah). 2000. Balanced Scorecard: Menerapkan Strategi Menjadi Aksi. Jakarta: Erlangga.

Krisbudiman, Arif. 2015. Penilaian Kinerja Kualitas Perusahaan Manufaktur PT. Yuasa Battery Indonesia dengan Metode Balance Scorecard. ISSN 2407-7852. Volume 1 No. 1

Lakshmi U. Tatikonda and Rao J. Tatikonda. 1998. We need dynamic performance meansures. US : Journal Management Accounting.

Monica, Steffi Gina. 2012. Perancangan Balanced Scorecard dalam Pengambilan Keputusan Strategik untuk perspektif Keuangan pada PT. Gajah Tunggal. Universitas Dian Nuswantoro. 


\section{JMM JUGNAL M MGSTERE MANAEEEN UNIVERSITAS MATARAM

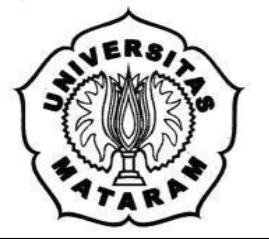

Mulyadi. Balanced Scorecard: Alat Manajemen Kontemporer untuk Pelipatganda Kinerja Keuangan Perusahaan. Edisi Ke-1. Penerbit Aditya Media. Yogyakarta. 1999.

Niven, Paul R. 2003. Balanced Scorecard Step by Step for Government and Non Profit Agencies. New jersey: John Willey \& Sons, Inc.

Puspita, Endah Kusuma. 2003. Penerapan model ukuran Balanced Scorecard pada PT. Semen Gresik (Persero) Tbk.

Pesanha, Diogo Santiago, dan Victor Prochnik. 2008. Practitioners Opinion on Academics Critics on The Balanced Scorecard. http;//papers.ssrn.com/sol3.

Sipayung, Friska. 2009. Balanced Scorecard: Pengukuran Kinerja Perusahaan dan Sistem Manajemen Strategis. Jurnal Manajemen Bisnis. Vol. 2, No.1: 7-14.

Tayler, Wiiliam. 2009. The Balanced Scorecard as a Strategy-Evaluation Tool: The Effects of Implementation Involvement and a Causal-Chain Focus. http://ssrn.com.

Widodo, Iman. 2010. Analisis Kinerja Perusahaan dengan Menggunakan Pendekatan Balanced Scorecard (Studi Kasus pada Perusahaan mebel PT. Jensen Indonesia).

Yunan, Rahma Diana Caesar. 2008. Penerapan Balanced Scorecard Sebagai Tolok Ukur Kinerja Manajemen pada PT Bank Tabungan Negara (Persero) Cabang Malang. Jurnal Akuntansi dan Keuangan, Vol. 10, No. 2, November. 